\title{
Thrombin Generation and Cancer: Contributors and Consequences
}

\author{
Caroline J. Reddel ${ }^{1}\left(\mathbb{D}\right.$, Chuen Wen Tan ${ }^{1,2}$ and Vivien M. Chen ${ }^{1,3, * \mathbb{C}}$ \\ 1 ANZAC Research Institute, University of Sydney, Concord 2139, Australia; creddel@anzac.edu.au (C.J.R.); \\ tan.chuen.wen@singhealth.com.sg (C.W.T.) \\ 2 Department of Haematology, Singapore General Hospital, Singapore 169608, Singapore \\ 3 Department of Haematology, Concord Hospital, Concord 2139, Australia \\ * Correspondence: vivien.chen@sydney.edu.au; Tel.: +61-2-9767-6834
}

Received: 1 December 2018; Accepted: 8 January 2019; Published: 16 January 2019

\begin{abstract}
The high occurrence of cancer-associated thrombosis is associated with elevated thrombin generation. Tumour cells increase the potential for thrombin generation both directly, through the expression and release of procoagulant factors, and indirectly, through signals that activate other cell types (including platelets, leukocytes and erythrocytes). Furthermore, cancer treatments can worsen these effects. Coagulation factors, including tissue factor, and inhibitors of coagulation are altered and extracellular vesicles (EVs), which can promote and support thrombin generation, are released by tumour and other cells. Some phosphatidylserine-expressing platelet subsets and platelet-derived EVs provide the surface required for the assembly of coagulation factors essential for thrombin generation in vivo. This review will explore the causes of increased thrombin production in cancer, and the availability and utility of tests and biomarkers. Increased thrombin production not only increases blood coagulation, but also promotes tumour growth and metastasis and as a consequence, thrombin and its contributors present opportunities for treatment of cancer-associated thrombosis and cancer itself.
\end{abstract}

Keywords: cancer; thrombosis; thrombin generation; platelets; procoagulant platelets; extracellular vesicles; neutrophil extracellular traps

\section{Introduction}

Patients with cancer are at high risk of pathological thrombosis with risk often exacerbated during cancer treatments. Central to thrombosis is thrombin, the serine protease responsible for the activation of platelets and the conversion of fibrinogen to fibrin. Markers of thrombin generation (both potential for ex vivo thrombin generation [1-4] and biomarkers indicating previous in vivo thrombin generation [5]) are elevated in patients with cancer, higher in malignant versus benign tumours [6], and negatively predict survival [7]. The implications of elevated levels of thrombin are far-reaching, as this not only indicates a hypercoagulable state and resultant increased risk of cancer-associated thrombosis [5,8] but also promotion of tumour growth and metastasis (reviewed in [9-11]). Many factors, both circulating and tumour-direct, contribute to this increased thrombin generation (Figure 1). This review will examine the major contributing factors. 


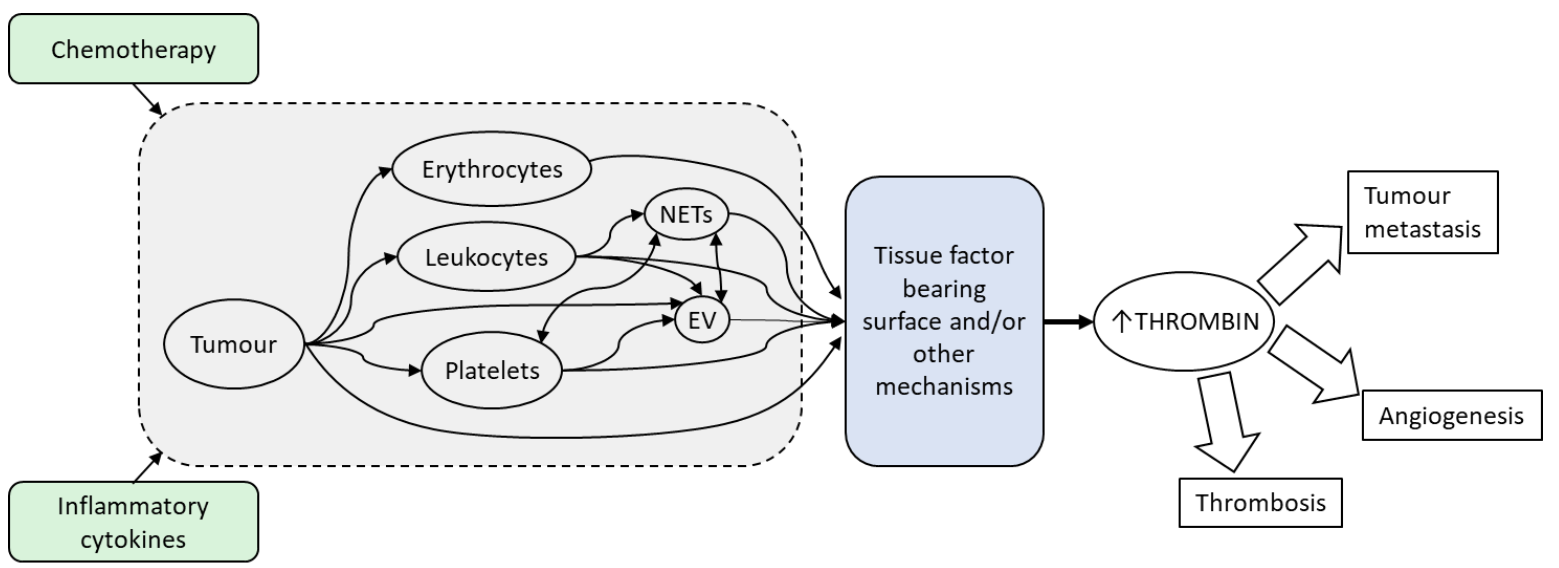

Figure 1. The high occurrence of cancer-associated thrombosis is associated with elevated thrombin generation. Tumour cells increase the potential for thrombin generation both directly, through the expression and release of procoagulant factors, and indirectly, through signals that activate other cell types and components including platelets, leukocytes, erythrocytes, extracellular vesicles (EVs) and neutrophil extracellular traps (NETs). Chemotherapy and the prevailing inflammatory milieu caused by the presence of cancer can stimulate tumour cells and other host cellular components to be procoagulant. Many of these factors potentiate thrombin generation through the expression of tissue factor bearing surfaces that mediates the assembly of coagulation factors essential for the formation of thrombin in vivo. Elevated thrombin production not only increases the risk of thrombosis, but also promotes tumour growth and metastasis and as a consequence, thrombin and its contributors present opportunities for treatment of cancer-associated thrombosis and the underlying cancer.

\section{Thrombin Generation Requires Activation of the Coagulation System and Membrane Surface Interaction}

In haemostasis, injury to the endothelium leads to the exposure of factors such as tissue factor (TF) and von Willebrand factor which signals tissue damage and triggers a cascading activation of coagulation factors and recruitment of platelets to the site of injury (reviewed in [12]). The coagulation factors, including prothrombinase complex (FVa and FXa), are assembled on a negatively charged phospholipid surface. Prothrombinase cleaves prothrombin, releasing thrombin and prothrombin fragments $1+2$, and eventually resulting in a burst of thrombin which converts fibrinogen to a fibrin clot. Thrombin is inhibited by antithrombin and is released in the form of thrombin-antithrombin (TAT) complexes.

Generation of thrombin thus requires a negatively charged phospholipid surface. During normal haemostasis, the surface is provided by phospholipid externalisation (predominantly phosphatidylserine) on the membrane of activated platelets and/or cell-derived extracellular vesicles (EVs). In cancer, this membrane surface may also be tumour-derived. EVs are small, submicron circulating components in the blood stream consisting of plasma membranes and cytosolic contents derived from the cell of origin. They include microvesicles $(<1000 \mathrm{~nm}$ membrane-derived EVs, also called microparticles), exosomes ( $<150 \mathrm{~nm}$ vesicles derived from multivesicular bodies), and apoptotic vesicles $(<5 \mu \mathrm{m}$ vesicles released from dying cells) and are released by many cellular sources including platelets, endothelial cells, red blood cells, leukocytes and cancer cells $[13,14]$. All these factors can be quantified in terms of their expression levels as well as their functional procoagulant activities. Current understanding in the EV field is that the sub-types cannot easily be distinguished from each other [15], and therefore this review applies the term EV to all such vesicles regardless of the nomenclature used in the cited articles.

Excessive thrombin generation and fibrin clot formation contributes to pathological thrombus. There are many factors that, when altered, can lead to the abnormal production of thrombin, many of which are affected by cancer. 


\section{Patients with Elevated Thrombin Generation are at Increased Risk of Cancer-Associated Thrombosis}

The potential for thrombin generation in patient plasma can be measured ex vivo by using a thrombin-specific substrate to measure the thrombin burst generated after exposure of plasma to an exogenous stimulant (usually tissue factor) in the presence or absence of blood cells (i.e., whole blood, platelet-rich plasma or cell-free plasma) [16]. The most standardised such test is the Calibrated Automated Thrombogram (CAT, Thrombinoscope BV, Maastricht, The Netherlands), which uses a fluorescent substrate. Technothrombin ${ }^{\circledR}$ TGA (Technoclone, Vienna, Austria) is similarly based on a fluorescent substrate. The ThromboPath assay (Instrumentation Laboratory, Bedford, OH, USA) is a similar chromogenic assay but which measures the effect of endogenous activated protein C (APC) in reducing thrombin generation [17].

Only a few prospective studies have assessed the association between elevated thrombin generation and cancer-associated thrombosis. The Vienna Cancer and Thrombosis Study (CATS) measured thrombin generation by the Technothrombin assay in platelet-free plasma in 1033 cancer patients, 77 of whom developed venous thromboembolism (VTE) within 2 years, and found that elevated thrombin generation (peak thrombin in the 75th percentile of the study population) was associated with an increased risk of VTE (hazard ratio of 2.1) [8]. Several smaller studies using the CAT assay have demonstrated similar findings to the CATS study; in 88 patients with malignant gynaecological cancers, thrombin generation was higher in the eight patients who went on to have a VTE after surgery [6], and in 36 multiple myeloma patients followed for 2.5 years, thrombin generation was higher in patients who later had thrombotic events than in those who did not [18]. The potential for thrombin generation [3] and resistance to protein C [19] appears to increase during treatment, corresponding with the increased risk of VTE. However, not all studies show the same association. In a study of 524 breast cancer patients (the CAVECCAS study), in which 56 patients developed a thrombus after venous catheter insertion, thrombin generation parameters by the CAT assay (and indeed any other biomarkers studied) were not predictive of this specific thrombus development [20]. Further prospective studies are needed to determine the predictive value of thrombin generation in different populations with cancer.

While the rapid inhibition of thrombin when generated in vivo means that it is not possible to capture real time thrombin formation in patients, assays are available that show evidence of previous thrombin generation by measuring the by-products of thrombin generation, such as prothrombin fragment $1+2(\mathrm{~F} 1+2)$ and thrombin-antithrombin (TAT) complexes. Increased risk of thrombosis is associated not only with increased propensity for thrombin generation but also with elevation of these markers of previous thrombin generation in vivo. In 821 patients from the Vienna Cancer and Thrombosis Study (62 with VTE within 8 months to 2 years) there was an increased risk of VTE associated with elevated F1+2 (HR of 2) and especially with elevated levels of both F1+2 and D-dimer (a product of fibrin degradation) [5]. High D-dimer levels have been identified in a number of studies as predictive of cancer-associated VTE (reviewed in [21]). High pre-operative TAT complexes predicted post-operative deep vein thrombosis (DVT) in 117 patients with solid tumours (nine with DVT) [22]. Taken together, patients at high risk of thrombosis are already generating high levels of thrombin even before potentially fatal events take place.

\section{Tumour-Specific Factors Contributing to Thrombin Generation}

The risk of thrombosis in cancer is associated with factors derived both from the tumour itself and host-related factors, illustrated by studies in which human tumours are introduced into murine models [23,24]. These models allow for isolation of host versus tumour elements by specific blocking of human and/or murine factors (reviewed in [25]). Some of the most important tumour-specific factors are described below. 


\subsection{Tumour Cells and Tissue Factor}

In vitro assays demonstrate that certain tumour cells, including solid cancers [26-30] and haematological malignancies [26,28], can directly support thrombin generation. In some tumours, this is related to expression of TF. Clinical epidemiological studies clearly demonstrate that the rate of cancer-associated thrombosis is influenced by cancer type and this is reflected in the clinical risk scores developed to predict thrombosis in ambulatory patients with pancreatic and gastric cancer weighted as highest risk, and lung, gynaecological, lymphoma, bladder or testicular tumours weighted as high risk compared with other cancers (Khorana, Vienna CATS and CONKO scores [31-33]). Tumour cells from certain cancers can directly express $\mathrm{TF}$, triggering thrombin generation, but in clinical prediction studies, VTE and tissue factor expression have only been consistently correlated in pancreatic cancer (reviewed in [21]). In vitro, there is a higher level of expression of TF by pancreatic cancer cells (BXPC3) than breast cancer cells (MCF7), corresponding with a higher thrombin generation potential of BXPC3 cells [34]. The thrombin generation activity of both cell types, and also the breast cancer line MDA-MB-231, is sensitive to inhibition by anti-TF antibody $[26,27,29]$. In one study, solid tumour cell lines (including pancreatic, ovarian, head and neck and lung) had a higher TF-dependent thrombin generation activity than malignant $B$ cell based haematological cell lines (multiple myeloma, plasma cell leukaemia, and histiocytic lymphoma) [28]. However, this does not hold true for all haematological cancers, as several studies indicate thrombin generation activity of leukaemia cell lines including acute promyelocytic leukaemia (NB4) and three monocytic leukaemia cell lines were highly sensitive to anti-TF inhibition [26,35]. Overall, the expression of TF on tumour cells and its effect on thrombin generation depends on the type of cancer.

The specific causative role of tumour-derived TF in thrombosis has been demonstrated by the introduction of human pancreatic cancer cells (expressing human TF) into mice [23]. In this study, anti-human TF reduced in vivo coagulation activation, indicating the tumour-derived TF was driving coagulation rather than the host. However, murine models with murine host TF and human cancer cell TF also indicate that host TF contributes to thrombosis [24].

\subsection{Tumour Cell-Derived and Tissue Factor Positive Extracellular Vesicles}

Circulating cancer cells also release EVs, providing another surface that contributes directly to thrombin generation in cancer. EV-free plasma is not able to generate thrombin [36], and cancer cell-derived EVs directly support thrombin generation, shown by in vitro studies of EVs released from leukaemia cell lines [35,37], prostate cancer cell lines [38] and breast and pancreatic cancer cell lines [39]. Many in vitro studies have linked expression of TF on EVs with their procoagulant potential (as measured by various functional assays such as thrombin generation performed in EV-enriched samples) [35,37,39-41]. Circulating TF-positive EVs (TF+EVs) have been seen in leukaemia [37], breast [39], pancreatic [39,42] and lung [42] cancer patients.

In vivo murine studies also support a causative role for cancer cell-derived EVs in thrombus formation. EVs derived from lung cancer cells [42] and breast cancer cells [43] infused into mice promote procoagulant activity in vivo. Cancer-derived TF+EVs can be found incorporated into thrombi of both ferric chloride and laser injury cremaster models of thrombi $[44,45]$. Furthermore, studies show that thrombus size in murine models is increased with infusion of pancreatic cancer cell-derived EVs or endogenous generated EVs in orthotopic models in a TF-dependent manner, with size and number of occlusive thrombi dependent on TF levels of the EVs [41,45]. EV-enhanced thrombosis is reduced by TF inhibition [41] or by prevention of EV incorporation into thrombus [42]. Furthermore, the thrombotic phenotype induced by TF+EV infusion is suppressed by direct thrombin inhibition with hirudin, indicating that the mechanism is related to thrombin generation [45].

When it comes to clinical samples, the evidence for and against the contribution of TF+EVs to increased thrombin generation in cancer thrombosis is more heterogeneous and mostly does not distinguish between tumour-specific EVs and EVs released by other cell types. Several clinical studies have identified an increased TF expression and/or activity on EVs in cancer patients [46-52] and 
especially in those who have previously had a thrombotic event (e.g., [51,53-55]). However, fewer studies have correlated TF levels with thrombin generation. Early studies have shown correlation between TF+EVs and activation of coagulation measured by D-dimer levels in colorectal cancer and early stage prostate cancer [52,56]. In contrast, in a small study of pancreatic cancer patients, EV-dependent thrombin generation in whole plasma was TF-dependent in only 1 of 13 cases [57], suggesting non-TF dependent mechanisms are also important in EV-associated thrombin generation in cancer.

Prospective studies in cancer using EV-dependent thrombin generation are extremely limited. In a small group of newly diagnosed acute leukaemia patients, both elevated EV-dependent thrombin generation activity and TF+EV activity (using the Zymuphen "MP-TF" activity assay) was associated with risk of thrombosis in the first week of treatment [58]. Prospective studies more generally investigating TF+EVs and/or TF-dependent procoagulant activity have produced varied results [21]. A recent trial showed an increased risk of VTE (HR 2.0) with elevated TF+EV-dependent procoagulant activity (based on FVII dependence in a fibrin generation test) prospectively measured in 648 cancer patients (40 of whom developed VTE within 6 months), and this risk was most pronounced in pancreatic cancer patients (HR 4.1) [59]. In a group of 43 cancer patients, TF-mediated procoagulant activity (factor Xa generation) on EVs was higher in five patients who developed VTE within six months than in the non-VTE group [60], and in another group of 60 cancer patients without VTE at the time of enrolment, four patients developed thromboembolic disease within a year and all were positive for TF+EVs [55]. In 117 patients with pancreatobiliary cancers, elevated TF activity on EVs ("MP-TF activity assay," in which large EVs were pelleted and used to trigger FXa generation in the presence or absence of an anti-TF antibody) was associated with VTE (OR 1.4) and lower survival [61]. EV-associated TF activity (using a similar "MP-TF activity assay") was similarly associated with lower survival in 50 patients with pancreatic or breast cancer [51].

A limitation of much of the current literature around EV contribution to thrombin generation in cancer is that many studies rely on differential centrifugation alone to separate EVs. While these methods enrich EVs they result in impure preparations [62,63]. Another problem remains that of standardisation of TF+EV thrombin generation measurement between laboratories. While commercial assays are available to measure $\mathrm{TF}+\mathrm{EV}$ coagulant activity, the sensitivity is relatively low [64]. Methodologies are variable with some studies isolating large EVs using ultracentrifugation prior to measuring ability to trigger coagulation, while others measure TF+EV coagulant activity directly in the plasma after recalcification. Assays are not yet standardised enough to allow measurements of tumour-derived TF+EV activity to guide clinical decisions.

\section{Host-Specific Factors Contributing to Thrombin Generation}

Tumour cells also hijack and alter host-specific factors in ways that promote thrombin generation and thrombosis. This section will address some of the relevant changes in host blood cells and host EVs and the inflammatory system.

\subsection{Platelet Procoagulant Activity and Platelet-Derived EV}

\subsubsection{Platelets and Platelet-Derived EV in Haemostasis}

Platelets play an essential role in thrombosis in both haemostatic and pathological conditions, including cancer-associated thrombosis. There is cumulative evidence demonstrating platelet heterogeneity with the existence of platelet subpopulations after stimulation with strong agonists [65-69]: aggregatory platelets contribute to the formation of platelet aggregation via activation of GPIIb-IIIa whilst procoagulant platelets participate in the coagulation processes leading to thrombin generation. The subset that form procoagulant platelets respond to potent agonist stimulation by an increase in intracellular $\mathrm{Ca}^{2+}$ which leads to externalisation of phosphatidylserine (PS) on the outer plasma membrane $[65,67,69,70]$ and supports prothrombinase activity to generate the thrombin 
burst $[65,69]$ (see Section 2). This localises the fibrin formation to the platelet aggregate and stabilises the thrombus.

Platelet-derived EVs, identified by glycoprotein receptors e.g., CD41 and CD42b, are thought to account for the majority of EVs in circulation [71]. Like activated platelets, they typically express platelet activation markers and PS on their outer membrane, facilitating the assembly of coagulation factors and thereby contributing to thrombin production. Some studies have found TF+EVs to co-express CD41 leading to speculation that tumour EVs may bind to platelets, then be re-shed as TF+platelet EVs [41,52], and suggesting that levels of TF activity in a combined platelet and EV sample may be a more accurate measure of thrombotic risk in patients with cancer compared with the TF activity of tumour EVs alone. Importantly, platelet-derived EVs are produced during the formation of procoagulant platelets, effectively increasing the membrane surface area capable of supporting thrombin generation [72-74].

Procoagulant effects of platelets and platelet-derived EVs can be assessed by several methods. As the PS exposure on the external membrane of platelets is a prerequisite for the assembly of coagulation factors on platelets and their associated EVs, flow cytometry-based assays to detect PS expression are often used as a surrogate for measurement of procoagulant platelets. Confocal microscopy can be used to visualise PS exposure as well as the binding of FVa and FXa on the membranes of platelets and EVs [75]. Procoagulant activity contributed by platelets and platelet EVs can be assessed by commercially available functional coagulation tests such as the CAT assay (see Section 3) and STA Procoag-PPL assay (Diagnostica Stago, Asnieres sur Seine, France) (using platelet-free but EV-containing plasma to assess procoagulant activity contributed by EVs). In addition, procoagulant activity of isolated platelets or platelet EVs can also be measured with in-house assays using either a single stage clotting assay or a 2-stage amidolytic assay to quantify the generation of thrombin and FXa [75-77]. Recently, a novel assay utilising GSAO [(4-(N-(S-glutathionylacetyl)amino)phenylarsonous acid] and P-selectin permits the direct identification of procoagulant platelets in whole blood by flow cytometry [78] and this may be useful in future studies of cancer thrombosis.

\subsubsection{Platelets and Platelet-Derived EV in Cancer-Associated Thrombosis}

Cancer causes increased platelet activation and aggregation, and these effects have been extensively reviewed [79-83]. Certain malignant cells can promote platelet activation through multiple pathways including direct activation by TF on the tumour or tumour EVs, tumour-derived thrombin generation leading to platelet activation via cleavage of platelet thrombin receptors PAR1 and PAR4, and tumour-derived cytokine and metalloprotease secretion (reviewed in $[80,81]$ ). In certain cancers, platelet activation and thrombosis rates are related to aberrant expression of platelet activating ligands on tumour cells such as the CLEC-2 ligand, podoplanin, on both glioblastoma and acute promyelocytic leukaemia $[84,85]$. Once activated, there is a large potential PS surface contribution from platelets for thrombin generation, as described above.

Procoagulant platelets and platelet-derived EVs and their associated enhanced procoagulant activities are increased in several solid organ malignancies. Phosphatidylserine-positive (PS+) procoagulant platelets are elevated in patients with gastric cancer [86], non-small cell lung cancer [87] and colon cancer [76]. Platelet-derived EVs are also elevated in patients with various cancers including gastrointestinal, breast, lung and prostatic malignancies [88], non-small cell lung cancer [87], colon cancer [76] and cutaneous malignant melanoma [89]. Both procoagulant platelets and platelet-derived EVs associate with tumour state. For example, both increase with stage of colon cancer [76], procoagulant platelets decrease with resection of gastric tumour [86] and platelet-derived EVs are higher in malignant breast [90] and ovarian [91] cancer compared with benign tumours. Platelet EV numbers associate with prior VTE in patients with cancer; patients with VTE had higher TF-expressing EVs than those without, and TF-expressing EVs were strongly correlated with platelet-derived EVs [88]. In another group of patients with soft tissue sarcoma in which the overall 
population of EVs was increased compared to healthy controls, activated platelet-derived EVs (defined as CD62P and CD63 positive population) were significantly elevated in patients with history of VTE than those without [82].

By performing functional procoagulant activity assays, several of these studies have additionally shown a link between elevated levels of procoagulant platelets or platelet-derived EVs and elevated thrombin generation. For example, both platelets and platelet-derived EVs from patients with colon cancer had elevated factor $\mathrm{Xa}$ and prothrombinase formation and thus thrombin generation [76], and platelets from patients with gastric cancer had enhanced procoagulant functions with higher prothrombinase activity [86]. Levels of platelet-derived EVs in cutaneous malignant melanoma correlated with procoagulant potential as measured by STA Procoag-PPL assay [89]. However, this relationship cannot be extrapolated to all cancers as plasma samples containing elevated platelet-derived EVs from patients with breast cancers did not show a correlation between levels of EVs and thrombin generation [90].

Perhaps the most consistent evidence for contribution of platelet-derived thrombin generation to thrombotic risk is seen in essential thrombocythaemia, a Philadelphia-negative myeloproliferative neoplasm (MPN) characterised by clonal proliferation of the megakaryocytic lineage within the bone marrow and elevated platelet count in peripheral blood. Up to $20 \%$ of patients have a history of thrombosis at diagnosis, and the ongoing rate of thrombus is between $1 \%$ and $4 \%$ per year despite current standard of care therapy [92,93]. Elevated levels of PS+ procoagulant platelets have been shown in several studies of patients with essential thrombocythaemia [94,95], and the related disorders of polycythaemia vera and myelofibrosis $[96,97]$. Furthermore, in these diseases, using identical total number of platelets as controls, patients' platelets (containing higher PS+ platelet subset) support higher thrombin and fibrin generation [75] suggesting a mechanistic link between the observed hypercoagulability and this platelet subset. Patients with both essential thrombocythaemia and polycythaemia rubra vera have heightened thrombin generation, measured in platelet-rich-plasma and platelet isolates, compared to controls. These findings support a causative role of procoagulant platelets in elevated thrombin generation contributing to hypercoagulability in MPN [98]. Patients with MPN and prior history of thrombosis also exhibit raised EV levels compared with patients without thrombosis [96], however the contribution of EVs to thrombin generation in MPN is less clear. Unlike the findings in platelet-rich plasma, two studies have found no increase in thrombin generation using the CAT assay in platelet-free plasma $[98,99]$, indicating that EVs may have a less significant functional role in thrombin generation in MPN. Interestingly, the same group found that platelet-free plasma from essential thrombocythaemia patients had increased peak thrombin (a CAT assay parameter) when thrombin generation was assayed in the presence of activated protein $C$ indicating that the EV contribution to thrombin generation may be acting via the protein $C$ pathway.

Overall, these findings point to a complex relationship between procoagulant platelets and platelet-derived EVs as potential markers of and contributors to cancer and cancer-associated thrombosis.

\subsection{Leukocyte-Derived Extracellular Vesicles and Tissue Factor}

Elevated systemic levels of leukocytes are associated with cancer, and with the risk of VTE (reviewed in [100]), and several studies have identified elevated levels of leukocyte-derived EVs in cancer [101-103]. However, little is currently known about the role of leukocyte-derived EVs, especially regarding their contribution to thrombosis. In healthy subjects and other diseases such as atherosclerosis, leukocyte-derived EVs play a wide variety of roles, not limited to procoagulant activities (reviewed in [104]).

Monocytes do not usually express TF, but highly express it in response to stimuli [105]. Capacity of monocytes to express active TF is increased in a range of thrombotic diseases (reviewed in [106]), including cancer. Elevated TF activity was observed in response to lipopolysaccharide stimulation in monocytes from bladder, prostate, breast and colorectal cancer patients compared with cells from 
healthy controls [107]. Monocytes from a group of patients with essential thrombocythaemia had higher levels of circulating TF than healthy controls, and within this patient group, those with previous VTE had increased capacity to express TF in response to lipopolysaccharide [108]. Further, monocytes from patients with polycythaemia vera had an increased capacity to express TF in response to endotoxin stimulation, which correlated with circulating F1+2 [109]. There is some evidence for a causative link between monocyte TF and thrombosis. In a rabbit model, leukocytes extracted from animals treated by injection of endotoxin which expressed a high level of TF activity were injected into healthy animals, causing widespread clots (compared with low TF leukocytes, which did not cause clots) [110].

In vitro studies demonstrate that stimulated monocytes release TF+EVs [111-113] and that monocyte-derived EVs have the capacity to trigger thrombin generation $[112,113]$. The thrombin generation activity of monocyte-derived EVs, like tumour-derived EVs, appears to be TF-dependent [113]. Overall, monocyte-derived EVs, in addition to tumour-derived EVs, could therefore contribute to the increased risk of thrombosis in cancer patients with high levels of EV-associated TF activity.

\subsection{Erythrocytes}

There is evidence to suggest that some erythrocytes with PS exposure could enhance thrombin generation in the setting of malignancy. There are more PS+ erythrocytes and erythrocyte-derived EVs from patients with polycythaemia rubra vera than healthy controls and those with secondary polycythaemia, and these PS+ erythrocytes and EVs exhibit increased procoagulant activity [114]. In addition, some chemotherapies could potentiate their procoagulant activity through erythrocytes: Zhou et al. showed that daunorubicin could increase PS exposure of erythrocytes in patients with acute myeloid leukaemia and these erythrocytes in turn exhibit enhanced thrombin generating potential [115].

\subsection{Inflammation}

Inflammation is central to the development and progression of cancer (reviewed in $[116,117])$. The tumour microenvironment contains neutrophils, dendritic cells and tumour-associated macrophages, and tumour cells release cytokines and chemokines. Leukocytes form part of the thrombotic response (reviewed in [118]) and there is a close interplay between inflammation and coagulation (reviewed in [119]). Some of the factors contributing to this are discussed below.

\subsubsection{Neutrophil Extracellular Traps (NETs)}

Activated neutrophils can expel neutrophil extracellular traps (NETs), networks of DNA, histones and cellular proteins which play a role in host defence, but also have detrimental effects in various diseases, including an association between markers of NETs and thrombosis/elevated thrombin generation/risk of VTE (e.g., sepsis [120,121], inflammatory bowel disease [122] and Cushings disease [123]). NETs are found in thrombotic material from patients [124,125], and in mice, blocking NET formation by knocking out protein arginine deiminase 4 (PAD4) greatly reduces thrombosis caused by an inferior vena cava ligation model of DVT [126] and reduces intravascular thrombin activity in a model of sepsis [127]. Ex vivo experiments using neutrophils from both mice [128] and humans $[120,129]$ show that NETs can trigger thrombin generation which is abolished by DNase treatment and factor XII inhibition [120,128]. One study found that cell-free DNA alone triggered thrombin generation, while intact NETs did not [130]. Histones infused into healthy mice increased markers of thrombin generation in vivo (and not when infused together with an antibody against histones) [131] and may have direct effects on thrombin generation or act indirectly e.g., via expression of TF on other cell types (reviewed in [132]). NETs may also express TF themselves (e.g., in the atherosclerotic plaque from ST-elevation myocardial infarction patients [124] or in an in vitro model of antineutrophil cytoplasmic antibody-associated vasculitis [133]) which could contribute to their procoagulant activities. 
Circulating markers of NETs are increased in patients with cancer $[125,134]$ and neutrophils from patients with cancer have a higher capacity to release NETs in vitro (e.g., gastric cancer [135], colorectal cancer [136], stage I/II oral squamous cell carcinoma [137], chronic lymphocytic leukaemia [138], but not Philadelphia-negative MPNs [139]). Mouse models of chronic myelogenous leukaemia, mammary and lung carcinoma also have increased sensitivity for NET formation [140]. Pancreatic cancer cells can induce NET formation from polymorphonuclear neutrophils in vitro [141] and in a mouse model of pancreatic cancer, blocking NET formation reduced hypercoagulability (as measured by thromboelastogram) and circulating TF [142]. In 936 patients from the Vienna Cancer and Thrombosis Study, citrullinated histone levels were significantly higher in the 89 who developed VTE within 2 years, with a SHR of 1.13 per $100 \mathrm{ng} / \mathrm{mL}$ increase. Cell-free DNA in the highest quartile was also associated with an increased risk of VTE [143].

NETs interact with both platelets (reviewed in [144]) and EVs. They can stimulate platelet activation [142] and procoagulant platelet formation [145], are involved in platelet adhesion to neutrophils [128], and are stimulated by P-selectin [146], which is highly expressed by activated platelets and released onto platelet-derived EVs. NETs may also act synergistically with EVs to promote procoagulant activity [128]. Furthermore, tumour EVs have been shown to localise to NETs with reduction in thrombus size when NET/EV interactions are disrupted [45]. Strategies to reduce NETs may be an additional mechanism to reduce thrombotic risk in cancer.

\subsubsection{Pro-Inflammatory Mediators}

Thrombin activates the complement system (reviewed in [147]), and cytokines and complements can activate the coagulation system. For example, IL- $1 \beta$ and TNF- $\alpha$ cause an increase in TF expression by vascular cells $[148,149]$. Identifying a clinical link between cytokines and thrombosis risk is not clear. The Vienna Cancer and Thrombosis Study found no association between VTE and any soluble inflammatory marker (except for a trend for the association of IL- $1 \beta$ and IL- 6 with VTE in pancreatic cancer) [150], although in another study, IL-6 was found to be an independent predictor of VTE in 200 patients with ovarian cancer (HR 8.9) [151]. In ovarian cancer, IL-6 increases thrombopoietin expression by hepatocytes, which increases platelet production by megakaryocytes (reviewed in [25]) providing an additional link between inflammation and platelet-dependent thrombin generation. Elevated E-selectin (an adhesion molecule on endothelial cells activated by cytokines) was an independent risk factor (OR 1.41) for postoperative DVT in a mixed group of cancer patients [152]. Infusion of IL-6 into patients with metastatic renal cell cancer caused elevated markers of thrombin generation [153], and in a mouse model of cancer cachexia with high, TF-independent thrombin generation, blocking tumour-derived IL-6 led to a decrease in thrombin generation by the CAT assay [154], implying a causative association between elevated cytokines and thrombosis in cancer.

\section{Chemotherapy Effects on Thrombin Generation}

Chemotherapy used in the management of cancer is considered a major factor for hypercoagulability in cancer patients. The direct tumour effect on thrombin generation may be exaggerated after chemotherapy, providing one explanation for the ensuing heightened procoagulant state. For example, cisplatin, carboplatin, gemcitabine and paclitaxel all increased TF activity on lung cancer cells in vitro [155] and cisplatin treatment may cause an increase in TF in germ cell tumour cells [156]. It is suspected that one mechanism for increased risk of VTE during chemotherapy is apoptotic vesicles released upon death of the tumour cells, which appear to be more procoagulant than microvesicles and are sensitive to anti-TF inhibition (recently reviewed in [157]). Cisplatin and gemcitabine also increased TF antigen and activity on monocytes in vitro [155]. The increased VTE risk of gemcitabine and platinum based therapies are incorporated into the PROTECHT clinical prediction risk score [158].

Platelets are also implicated as critical contributors to this thrombogenic process after chemotherapy. Doxorubicin-treated platelets displayed higher levels of phosphotidylserine, 
increased intracellular calcium and generated more thrombin than untreated controls [159], and doxorubicin increased platelet mitochondrial inner transmembrane potential depolarisation in a concentration and time dependent manner [160], consistent with the phenotype of procoagulant platelet. These procoagulant platelet effects also follow doxorubicin exposure in an in vivo rat thrombosis model [159]. Patients with non-small cell lung cancer had increased procoagulant platelets and platelet-derived EV levels after treatment with combination gemcitabine and cisplatin chemotherapy [87]. Moreover, there was enhanced platelet-dependent thrombin and fibrin formation observed post-chemotherapy and use of aspirin partially attenuated this enhanced platelet-induced procoagulant activity in vitro [87]. Further, arsenic therapy in the treatment of acute promyelocytic leukaemia has been shown to potentiate PS exposure on platelets. These platelets displayed increased intracellular calcium and generated more thrombin and were related to increased thrombosis in a rat model of thrombosis [161]. The fact that these effects are mediated by procoagulant platelets suggests a potential novel intervention to decrease hypercoagulability after chemotherapy.

\section{Thrombin Role in Tumour Biology/Metastasis}

The role thrombin plays in the protection and promotion of tumours has been comprehensively reviewed (e.g., [9-11]). There is considerable evidence from animal models that thrombin augments tumour growth and metastasis (reviewed in [162]). For example, thrombin increases metastases when tumour cells are injected into mice in its presence [163], reduction of circulating prothrombin levels reduces tumour growth in a colon cancer model [164] and inhibition of thrombin in a breast cancer model reduces bone metastasis [165]. The thrombin receptors protease activating receptor (PAR)-1 and -2 are expressed on a broad range of tumour cells, and activation of these receptors has effects which include tumour growth, cell proliferation, migration, invasion and increased inflammation and angiogenesis (reviewed in [166]). Further, thrombin appears to alter gene expression of tumour cells to promote oncogenesis (reviewed in [167]). Tumour cells may also express TF on the cell surface to aid the process of epithelial-mesenchymal transition and thus increasing their metastatic potential [168].

In addition to these direct functions, thrombin promotes cancer progression and metastasis via platelets. Thrombin activates platelets [169] and promotes their interactions with tumour cells [163]. The fact that platelets play an important role in tumour growth and metastasis has been thoroughly and recently reviewed [170-177]. Platelet count correlates with poor prognosis (reviewed in [171]) and inhibition of platelets inhibits metastasis in vitro and in animal models (reviewed in [173]). Platelets facilitate tumourigenesis by mechanisms including the secretion of factors (reviewed in [170]) promoting tumour cell proliferation (e.g., transforming growth factor- $\beta 1$ ), pro-angiogenic factors (e.g., vascular endothelial growth factor and platelet-derived growth factor) and changes in cellular expression including promotion of the epithelial-mesenchymal transition [171,175]. Platelets also directly interact with endothelial cells to induce angiogenesis [174]. Circulating tumour cells are stabilised by platelet and fibrin aggregates forming around them, protecting them from shear forces and host immunity, and promoting invasion $[167,170,171,176]$. The promotion of thrombin in cancer thus forms a positive feedback loop, with not only potentially fatal effects on coagulation but also further propagation of the disease.

\section{Conclusions}

There are a number of systemic and tumour-driven changes in cancer which support thrombin generation. Studies in the pathogenesis of cancer indicate a key role for thrombin in tumour progression, however no single assay has been able to predict risk of thrombosis and outcome in all cancers, pointing to the complexity and multi-factorial nature of this phenomenon. Haemostatic tests, such as the thrombin generation assay, show some promise, but these are not yet standardised and to date, there have been few prospective studies that show the association between elevated global thrombin generation and cancer-associated thrombosis. 
While evidence is building strongly for a role for tumour- and host-derived EVs in cancer-associated thrombin generation and thrombosis, and as methods become more established and standardised, prospective studies are still needed to determine the association between circulating cells, cell-derived factors and thrombosis. The increased thrombotic risk is also directly contributed to by tumour cells and tumour-educated blood cells, including platelets, indicating the importance of assessing the cellular and EV procoagulant potential. This is a promising field in which understanding the pathophysiology of the drivers of cancer associated thrombin generation may eventually lead to risk scores to predict cancer related thrombosis and targeted interventions that address the individual risk factors driving thrombosis in cancer patients.

Funding: This research was funded by a Concord Cancer Centre Research Grant. C.W.T is supported by SingHealth Foundation Health Manpower Development Programme, Singapore.

Acknowledgments: The authors thank Ibrahim Tohidi-Esfahani for proof-reading the article.

Conflicts of Interest: The authors declare no conflict of interest.

\section{References}

1. Lim, H.Y.; Ng, C.; Rigano, J.; Tacey, M.; Donnan, G.; Nandurkar, H.; Ho, P. An evaluation of global coagulation assays in myeloproliferative neoplasm. Blood Coagul. Fibrinolysis 2018, 29, 300-306. [CrossRef] [PubMed]

2. Benyo, M.; Flasko, T.; Molnar, Z.; Kerenyi, A.; Batta, Z.; Jozsa, T.; Harsfalvi, J. Follow-up of thrombin generation after prostate cancer surgery: Global test for increased hypercoagulability. PLoS ONE 2012, 7, e51299. [CrossRef]

3. Tiong, I.S.; Rodgers, S.E.; Lee, C.H.; McRae, S.J. Baseline and treatment-related changes in thrombin generation in patients with multiple myeloma. Leuk Lymphoma 2017, 58, 941-949. [CrossRef] [PubMed]

4. Chaari, M.; Ayadi, I.; Rousseau, A.; Lefkou, E.; Van Dreden, P.; Sidibe, F.; Ketatni, H.; Galea, V.; Khaterchi, A.; Bouzguenda, R.; et al. Impact of breast cancer stage, time from diagnosis and chemotherapy on plasma and cellular biomarkers of hypercoagulability. BMC Cancer 2014, 14, 991. [CrossRef]

5. Ay, C.; Vormittag, R.; Dunkler, D.; Simanek, R.; Chiriac, A.L.; Drach, J.; Quehenberger, P.; Wagner, O.; Zielinski, C.; Pabinger, I. D-dimer and prothrombin fragment $1+2$ predict venous thromboembolism in patients with cancer: Results from the Vienna Cancer and Thrombosis Study. J. Clin. Oncol. 2009, 27, 4124-4129. [CrossRef]

6. Abu Saadeh, F.; Langhe, R.; Galvin, D.M.; Sa, O.T.; O'Donnell, D.M.; Gleeson, N.; Norris, L.A. Procoagulant activity in gynaecological cancer patients; the effect of surgery and chemotherapy. Thromb. Res. 2016, 139, 135-141. [CrossRef]

7. Ferroni, P.; Martini, F.; Portarena, I.; Grenga, I.; Riondino, S.; La Farina, F.; Laudisi, A.; Roselli, M.; Guadagni, F. An activated protein C-dependent thrombin generation assay predicts chemotherapy-associated venous thromboembolism in cancer patients. Thromb. Haemost. 2011, 105, 931-932. [CrossRef]

8. Ay, C.; Dunkler, D.; Simanek, R.; Thaler, J.; Koder, S.; Marosi, C.; Zielinski, C.; Pabinger, I. Prediction of venous thromboembolism in patients with cancer by measuring thrombin generation: Results from the Vienna Cancer and Thrombosis Study. J. Clin. Oncol. Off. J. Am. Soc. Clin. Oncol. 2011, 29, 2099-2103. [CrossRef] [PubMed]

9. Green, D.; Karpatkin, S. Role of thrombin as a tumor growth factor. Cell Cycle 2010, 9, 656-661. [CrossRef]

10. Wojtukiewicz, M.Z.; Hempel, D.; Sierko, E.; Tucker, S.C.; Honn, K.V. Thrombin-unique coagulation system protein with multifaceted impacts on cancer and metastasis. Cancer Metastasis Rev. 2016, 35, 213-233. [CrossRef]

11. Remiker, A.S.; Palumbo, J.S. Mechanisms coupling thrombin to metastasis and tumorigenesis. Thromb. Res. 2018, 164 (Suppl. 1), S29-S33. [CrossRef] [PubMed]

12. Wolberg, A.S.; Campbell, R.A. Thrombin generation, fibrin clot formation and hemostasis. Transfus. Apher. Sci. 2008, 38, 15-23. [CrossRef] [PubMed]

13. Rak, J. Microparticles in cancer. Semin. Thromb. Hemost. 2010, 36, 888-906. [CrossRef]

14. Yanez-Mo, M.; Siljander, P.R.; Andreu, Z.; Zavec, A.B.; Borras, F.E.; Buzas, E.I.; Buzas, K.; Casal, E.; Cappello, F.; Carvalho, J.; et al. Biological properties of extracellular vesicles and their physiological functions. J. Extracell. Vesicles 2015, 4, 27066. [CrossRef] [PubMed] 
15. Théry, C.; Witwer, K.W.; Aikawa, E.; Alcaraz, M.J.; Anderson, J.D.; Andriantsitohaina, R.; Antoniou, A.; Arab, T.; Archer, F.; Atkin-Smith, G.K.; et al. Minimal information for studies of extracellular vesicles 2018 (MISEV2018): A position statement of the International Society for Extracellular Vesicles and update of the MISEV2014 guidelines. J. Extracell. Vesicles 2018, 7, 1535750. [CrossRef]

16. Kintigh, J.; Monagle, P.; Ignjatovic, V. A review of commercially available thrombin generation assays. Res. Pract. Thromb. Haemost. 2018, 2, 42-48. [CrossRef]

17. Toulon, P.; Smirnov, M.; Triscott, M.; Safa, O.; Biguzzi, E.; Bouziane, K.; Tripodi, A. A new chromogenic assay (HemosIL ThromboPath) is sensitive to major prothrombotic risk factors affecting the protein $\mathrm{C}$ pathway. Results of a multicenter study. Thromb. Res. 2009, 124, 137-143. [CrossRef]

18. Leiba, M.; Malkiel, S.; Budnik, I.; Rozic, G.; Avigdor, A.; Duek, A.; Nagler, A.; Kenet, G.; Livnat, T. Thrombin generation as a predictor of thromboembolic events in multiple myeloma patients. Blood Cells Mol. Dis. 2017, 65, 1-7. [CrossRef] [PubMed]

19. Roselli, M.; Ferroni, P.; Riondino, S.; Mariotti, S.; Laudisi, A.; Vergati, M.; Cavaliere, F.; Palmirotta, R.; Guadagni, F. Impact of chemotherapy on activated protein C-dependent thrombin generation-association with VTE occurrence. Int. J. Cancer J. Int. Du Cancer 2013, 133, 1253-1258. [CrossRef] [PubMed]

20. Debourdeau, P.; Espie, M.; Chevret, S.; Gligorov, J.; Elias, A.; Dupre, P.F.; Desseaux, K.; Kalidi, I.; Villiers, S.; Giachetti, S.; et al. Incidence, risk factors, and outcomes of central venous catheter-related thromboembolism in breast cancer patients: The CAVECCAS study. Cancer Med. 2017, 6, 2732-2744. [CrossRef]

21. Pabinger, I.; Thaler, J.; Ay, C. Biomarkers for prediction of venous thromboembolism in cancer. Blood 2013, 122, 2011-2018. [CrossRef] [PubMed]

22. Falanga, A.; Ofosu, F.A.; Cortelazzo, S.; Delaini, F.; Consonni, R.; Caccia, R.; Longatti, S.; Maran, D.; Rodeghiero, F.; Pogliani, E.; et al. Preliminary study to identify cancer patients at high risk of venous thrombosis following major surgery. Br. J. Haematol. 1993, 85, 745-750. [CrossRef] [PubMed]

23. Wang, J.G.; Geddings, J.E.; Aleman, M.M.; Cardenas, J.C.; Chantrathammachart, P.; Williams, J.C.; Kirchhofer, D.; Bogdanov, V.Y.; Bach, R.R.; Rak, J.; et al. Tumor-derived tissue factor activates coagulation and enhances thrombosis in a mouse xenograft model of human pancreatic cancer. Blood 2012, 119, 5543-5552. [CrossRef]

24. Stark, K.; Schubert, I.; Joshi, U.; Kilani, B.; Hoseinpour, P.; Thakur, M.; Grunauer, P.; Pfeiler, S.; Schmidergall, T.; Stockhausen, S.; et al. Distinct Pathogenesis of Pancreatic Cancer Microvesicle-Associated Venous Thrombosis Identifies New Antithrombotic Targets In Vivo. Arter. Thromb. Vasc. Biol. 2018, 38, 772-786. [CrossRef]

25. Hisada, Y.; Mackman, N. Cancer-associated pathways and biomarkers of venous thrombosis. Blood 2017, 130, 1499-1506. [CrossRef]

26. Marchetti, M.; Diani, E.; ten Cate, H.; Falanga, A. Characterization of the thrombin generation potential of leukemic and solid tumor cells by calibrated automated thrombography. Haematologica 2012, 97, 1173-1180. [CrossRef] [PubMed]

27. Rondon, A.M.R.; de Almeida, V.H.; Gomes, T.; Vercoza, B.R.F.; Carvalho, R.S.; Konig, S.; Rodrigues, J.C.F.; Mermelstein, C.D.S.; Versteeg, H.H.; Monteiro, R.Q. Tissue factor mediates microvesicles shedding from MDA-MB-231 breast cancer cells. Biochem. Biophys. Res. Commun. 2018, 502, 137-144. [CrossRef] [PubMed]

28. Adesanya, M.A.; Maraveyas, A.; Madden, L. Differing mechanisms of thrombin generation in live haematological and solid cancer cells determined by calibrated automated thrombography. Blood Coagul. Fibrinolysis 2017, 28, 602-611. [CrossRef]

29. Rousseau, A.; Larsen, A.K.; Van Dreden, P.; Sabbah, M.; Elalamy, I.; Gerotziafas, G.T. Differential contribution of tissue factor and Factor XII to thrombin generation triggered by breast and pancreatic cancer cells. Int. J. Oncol. 2017, 51, 1747-1756. [CrossRef]

30. Sassi, M.; Chakroun, T.; Mbemba, E.; Van Dreden, P.; Elalamy, I.; Larsen, A.K.; Gerotziafas, G.T. The Antithrombotic Potential of Tinzaparin and Enoxaparin Upon Thrombin Generation Triggered In Vitro by Human Ovarian Cancer Cells IGROV1. Clin. Appl. Thromb. Hemost. 2017, 23, 155-163. [CrossRef]

31. Khorana, A.A.; Kuderer, N.M.; Culakova, E.; Lyman, G.H.; Francis, C.W. Development and validation of a predictive model for chemotherapy-associated thrombosis. Blood 2008, 111, 4902-4907. [CrossRef]

32. Ay, C.; Dunkler, D.; Marosi, C.; Chiriac, A.L.; Vormittag, R.; Simanek, R.; Quehenberger, P.; Zielinski, C.; Pabinger, I. Prediction of venous thromboembolism in cancer patients. Blood 2010, 116, 5377-5382. [CrossRef] [PubMed] 
33. Pelzer, U.; Sinn, M.; Stieler, J.; Riess, H. Primary pharmacological prevention of thromboembolic events in ambulatory patients with advanced pancreatic cancer treated with chemotherapy? Dtsch. Med. Wochenschr. 2013, 138, 2084-2088. [CrossRef] [PubMed]

34. Gerotziafas, G.T.; Galea, V.; Mbemba, E.; Khaterchi, A.; Sassi, M.; Baccouche, H.; Prengel, C.; van Dreden, P.; Hatmi, M.; Bernaudin, J.F.; et al. Tissue factor over-expression by human pancreatic cancer cells BXPC3 is related to higher prothrombotic potential as compared to breast cancer cells MCF7. Thromb. Res. 2012, 129, 779-786. [CrossRef] [PubMed]

35. Hudak, R.; Debreceni, I.B.; Deak, I.; Szabo, G.G.; Hevessy, Z.; Antal-Szalmas, P.; Osterud, B.; Kappelmayer, J. Laboratory characterization of leukemic cell procoagulants. Clin. Chem. Lab. Med. 2017, 55, 1215-1223. [CrossRef] [PubMed]

36. Tripisciano, C.; Weiss, R.; Eichhorn, T.; Spittler, A.; Heuser, T.; Fischer, M.B.; Weber, V. Different Potential of Extracellular Vesicles to Support Thrombin Generation: Contributions of Phosphatidylserine, Tissue Factor, and Cellular Origin. Sci. Rep. 2017, 7, 6522. [CrossRef]

37. Gheldof, D.; Mullier, F.; Bailly, N.; Devalet, B.; Dogne, J.M.; Chatelain, B.; Chatelain, C. Microparticle bearing tissue factor: A link between promyelocytic cells and hypercoagulable state. Thromb. Res. 2014, 133, 433-439. [CrossRef]

38. Al Saleh, H.A.; Haas-Neill, S.; Al-Hashimi, A.; Kapoor, A.; Shayegan, B.; Austin, R.C.; Al-Nedawi, K. Thrombotic characteristics of extracellular vesicles derived from prostate cancer cells. Prostate 2018. [CrossRef]

39. Rousseau, A.; Van Dreden, P.; Khaterchi, A.; Larsen, A.K.; Elalamy, I.; Gerotziafas, G.T. Procoagulant microparticles derived from cancer cells have determinant role in the hypercoagulable state associated with cancer. Int. J. Oncol. 2017, 51, 1793-1800. [CrossRef]

40. Gomes, F.G.; Sandim, V.; Almeida, V.H.; Rondon, A.M.R.; Succar, B.B.; Hottz, E.D.; Leal, A.C.; Vercoza, B.R.F.; Rodrigues, J.C.F.; Bozza, P.T.; et al. Breast-cancer extracellular vesicles induce platelet activation and aggregation by tissue factor-independent and -dependent mechanisms. Thromb. Res. 2017, 159, $24-32$. [CrossRef]

41. Geddings, J.E.; Hisada, Y.; Boulaftali, Y.; Getz, T.M.; Whelihan, M.; Fuentes, R.; Dee, R.; Cooley, B.C.; Key, N.S.; Wolberg, A.S.; et al. Tissue factor-positive tumor microvesicles activate platelets and enhance thrombosis in mice. J. Thromb. Haemost. 2016, 14, 153-166. [CrossRef] [PubMed]

42. Thomas, G.M.; Panicot-Dubois, L.; Lacroix, R.; Dignat-George, F.; Lombardo, D.; Dubois, C. Cancer cell-derived microparticles bearing P-selectin glycoprotein ligand 1 accelerate thrombus formation in vivo. J. Exp. Med. 2009, 206, 1913-1927. [CrossRef]

43. Davila, M.; Amirkhosravi, A.; Coll, E.; Desai, H.; Robles, L.; Colon, J.; Baker, C.H.; Francis, J.L. Tissue factor-bearing microparticles derived from tumor cells: Impact on coagulation activation. J. Thromb. Haemost. 2008, 6, 1517-1524. [CrossRef]

44. Hisada, Y.; Ay, C.; Auriemma, A.C.; Cooley, B.C.; Mackman, N. Human pancreatic tumors grown in mice release tissue factor-positive microvesicles that increase venous clot size. J. Thromb. Haemost. 2017, 15, 2208-2217. [CrossRef] [PubMed]

45. Thomas, G.M.; Brill, A.; Mezouar, S.; Crescence, L.; Gallant, M.; Dubois, C.; Wagner, D.D. Tissue factor expressed by circulating cancer cell-derived microparticles drastically increases the incidence of deep vein thrombosis in mice. J. Thromb. Haemost. 2015, 13, 1310-1319. [CrossRef]

46. Thaler, J.; Koder, S.; Kornek, G.; Pabinger, I.; Ay, C. Microparticle-associated tissue factor activity in patients with metastatic pancreatic cancer and its effect on fibrin clot formation. Transl. Res. J. Lab. Clin. Med. 2014, 163, 145-150. [CrossRef] [PubMed]

47. Angelini, A.; Miscia, S.; Centurione, M.A.; Di Pietro, R.; Centurione, L. Predictive value of microparticle-associated tissue factor activity for permeability glycoprotein-mediated multidrug resistance in cancer. Oncol. Lett. 2016, 12, 3273-3277. [CrossRef]

48. Ma, G.; Liu, F.; Lv, L.; Gao, Y.; Su, Y. Increased promyelocytic-derived microparticles: A novel potential factor for coagulopathy in acute promyelocytic leukemia. Ann. Hematol. 2013, 92, 645-652. [CrossRef]

49. Debaugnies, F.; Azerad, M.A.; Noubouossie, D.; Rozen, L.; Hemker, H.C.; Corazza, F.; Efira, A.; Demulder, A. Evaluation of the procoagulant activity in the plasma of cancer patients using a thrombin generation assay. Thromb. Res. 2010, 126, 531-535. [CrossRef] 
50. Trappenburg, M.C.; van Schilfgaarde, M.; Bredewold, E.O.; van Aalderen, M.C.; Spronk, H.M.; Ten Cate, H.; Leyte, A.; Terpstra, W.E. Elevated numbers and altered subsets of procoagulant microparticles in breast cancer patients using endocrine therapy. Thromb. Res. 2011, 127, 363-369. [CrossRef]

51. Tesselaar, M.E.; Romijn, F.P.; Van Der Linden, I.K.; Prins, F.A.; Bertina, R.M.; Osanto, S. Microparticle-associated tissue factor activity: A link between cancer and thrombosis? J. Thromb. Haemost. 2007, 5, 520-527. [CrossRef] [PubMed]

52. Hron, G.; Kollars, M.; Weber, H.; Sagaster, V.; Quehenberger, P.; Eichinger, S.; Kyrle, P.A.; Weltermann, A. Tissue factor-positive microparticles: Cellular origin and association with coagulation activation in patients with colorectal cancer. Thromb. Haemost. 2007, 97, 119-123. [CrossRef] [PubMed]

53. Manly, D.A.; Wang, J.; Glover, S.L.; Kasthuri, R.; Liebman, H.A.; Key, N.S.; Mackman, N. Increased microparticle tissue factor activity in cancer patients with Venous Thromboembolism. Thromb. Res. 2010, 125, 511-512. [CrossRef]

54. Taniguchi, Y.; Tanaka, H.; Luis, E.J.; Sakai, K.; Kumode, T.; Sano, K.; Serizawa, K.; Rai, S.; Morita, Y.; Hanamoto, H.; et al. Elevated plasma levels of procoagulant microparticles are a novel risk factor for thrombosis in patients with myeloproliferative neoplasms. Int. J. Hematol. 2017, 106, 691-703. [CrossRef]

55. Zwicker, J.I.; Liebman, H.A.; Neuberg, D.; Lacroix, R.; Bauer, K.A.; Furie, B.C.; Furie, B. Tumor-derived tissue factor-bearing microparticles are associated with venous thromboembolic events in malignancy. Clin. Cancer Res. 2009, 15, 6830-6840. [CrossRef] [PubMed]

56. Haubold, K.; Rink, M.; Spath, B.; Friedrich, M.; Chun, F.K.; Marx, G.; Amirkhosravi, A.; Francis, J.L.; Bokemeyer, C.; Eifrig, B.; et al. Tissue factor procoagulant activity of plasma microparticles is increased in patients with early-stage prostate cancer. Thromb. Haemost. 2009, 101, 1147-1155. [PubMed]

57. Hellum, M.; Franco-Lie, I.; Ovstebo, R.; Hauge, T.; Henriksson, C.E. The effect of corn trypsin inhibitor, anti-tissue factor pathway inhibitor antibodies and phospholipids on microvesicle-associated thrombin generation in patients with pancreatic cancer and healthy controls. PLoS ONE 2017, 12, e0184579. [CrossRef] [PubMed]

58. Gheldof, D.; Haguet, H.; Dogne, J.M.; Bouvy, C.; Graux, C.; George, F.; Sonet, A.; Chatelain, C.; Chatelain, B.; Mullier, F. Procoagulant activity of extracellular vesicles as a potential biomarker for risk of thrombosis and DIC in patients with acute leukaemia. J. Thromb. Thrombolysis 2017, 43, 224-232. [CrossRef] [PubMed]

59. van Es, N.; Hisada, Y.; Di Nisio, M.; Cesarman, G.; Kleinjan, A.; Mahe, I.; Otten, H.M.; Kamphuisen, P.W.; Berckmans, R.J.; Buller, H.R.; et al. Extracellular vesicles exposing tissue factor for the prediction of venous thromboembolism in patients with cancer: A prospective cohort study. Thromb. Res. 2018, 166, 54-59. [CrossRef]

60. van Doormaal, F.; Kleinjan, A.; Berckmans, R.J.; Mackman, N.; Manly, D.; Kamphuisen, P.W.; Richel, D.J.; Buller, H.R.; Sturk, A.; Nieuwland, R. Coagulation activation and microparticle-associated coagulant activity in cancer patients. An exploratory prospective study. Thromb. Haemost. 2012, 108, 160-165. [CrossRef]

61. Bharthuar, A.; Khorana, A.A.; Hutson, A.; Wang, J.G.; Key, N.S.; Mackman, N.; Iyer, R.V. Circulating microparticle tissue factor, thromboembolism and survival in pancreaticobiliary cancers. Thromb. Res. 2013, 132, 180-184. [CrossRef] [PubMed]

62. Van Deun, J.; Mestdagh, P.; Sormunen, R.; Cocquyt, V.; Vermaelen, K.; Vandesompele, J.; Bracke, M.; De Wever, O.; Hendrix, A. The impact of disparate isolation methods for extracellular vesicles on downstream RNA profiling. J. Extracell. Vesicles 2014, 3. [CrossRef] [PubMed]

63. Coumans, F.A.W.; Brisson, A.R.; Buzas, E.I.; Dignat-George, F.; Drees, E.E.E.; El-Andaloussi, S.; Emanueli, C.; Gasecka, A.; Hendrix, A.; Hill, A.F.; et al. Methodological Guidelines to Study Extracellular Vesicles. Circ. Res. 2017, 120, 1632-1648. [CrossRef] [PubMed]

64. Gardiner, C.; Harrison, P.; Belting, M.; Boing, A.; Campello, E.; Carter, B.S.; Collier, M.E.; Coumans, F.; Ettelaie, C.; van Es, N.; et al. Extracellular vesicles, tissue factor, cancer and thrombosis-Discussion themes of the ISEV 2014 Educational Day. J. Extracell. Vesicles 2015, 4, 26901. [CrossRef]

65. Heemskerk, J.W.; Mattheij, N.J.; Cosemans, J.M. Platelet-based coagulation: Different populations, different functions. J. Thromb. Haemost. 2013, 11, 2-16. [CrossRef]

66. Kempton, C.L.; Hoffman, M.; Roberts, H.R.; Monroe, D.M. Platelet heterogeneity: Variation in coagulation complexes on platelet subpopulations. Arter. Thromb. Vasc. Biol. 2005, 25, 861-866. [CrossRef]

67. Hua, V.M.; Abeynaike, L.; Glaros, E.; Campbell, H.; Pasalic, L.; Hogg, P.J.; Chen, V.M. Necrotic platelets provide a procoagulant surface during thrombosis. Blood 2015, 126, 2852-2862. [CrossRef] 
68. Dale, G.L. Procoagulant Platelets: Further Details but Many More Questions. Arter. Thromb. Vasc. Biol. 2017, 37, 1596-1597. [CrossRef]

69. Fager, A.M.; Wood, J.P.; Bouchard, B.A.; Feng, P.; Tracy, P.B. Properties of procoagulant platelets: Defining and characterizing the subpopulation binding a functional prothrombinase. Arter. Thromb. Vasc. Biol. 2010, 30, 2400-2407. [CrossRef]

70. Agbani, E.O.; van den Bosch, M.T.; Brown, E.; Williams, C.M.; Mattheij, N.J.; Cosemans, J.M.; Collins, P.W.; Heemskerk, J.W.; Hers, I.; Poole, A.W. Coordinated Membrane Ballooning and Procoagulant Spreading in Human Platelets. Circulation 2015, 132, 1414-1424. [CrossRef]

71. Aatonen, M.T.; Ohman, T.; Nyman, T.A.; Laitinen, S.; Gronholm, M.; Siljander, P.R. Isolation and characterization of platelet-derived extracellular vesicles. J. Extracell. Vesicles 2014, 3. [CrossRef]

72. Hughes, M.; Hayward, C.P.; Warkentin, T.E.; Horsewood, P.; Chorneyko, K.A.; Kelton, J.G. Morphological analysis of microparticle generation in heparin-induced thrombocytopenia. Blood 2000, 96, 188-194. [PubMed]

73. Owens, A.P., 3rd; Mackman, N. Microparticles in hemostasis and thrombosis. Circ. Res. 2011, 108, $1284-1297$. [CrossRef] [PubMed]

74. Berckmans, R.J.; Nieuwland, R.; Boing, A.N.; Romijn, F.P.; Hack, C.E.; Sturk, A. Cell-derived microparticles circulate in healthy humans and support low grade thrombin generation. Thromb. Haemost. 2001, 85, 639-646. [PubMed]

75. Tong, D.; Yu, M.; Guo, L.; Li, T.; Li, J.; Novakovic, V.A.; Dong, Z.; Tian, Y.; Kou, J.; Bi, Y.; et al. Phosphatidylserine-exposing blood and endothelial cells contribute to the hypercoagulable state in essential thrombocythemia patients. Ann. Hematol. 2018, 97, 605-616. [CrossRef] [PubMed]

76. Zhao, L.; Bi, Y.; Kou, J.; Shi, J.; Piao, D. Phosphatidylserine exposing-platelets and microparticles promote procoagulant activity in colon cancer patients. J. Exp. Clin. Cancer Res. 2016, 35, 54. [CrossRef]

77. Gao, C.; Xie, R.; Yu, C.; Wang, Q.; Shi, F.; Yao, C.; Zhou, J.; Gilbert, G.E.; Shi, J. Procoagulant activity of erythrocytes and platelets through phosphatidylserine exposure and microparticles release in patients with nephrotic syndrome. Thromb. Haemost. 2012, 107, 681-689. [CrossRef]

78. Pasalic, L.; Wing-Lun, E.; Lau, J.K.; Campbell, H.; Pennings, G.J.; Lau, E.; Connor, D.; Liang, H.P.; Muller, D.; Kritharides, L.; et al. Novel assay demonstrates that coronary artery disease patients have heightened procoagulant platelet response. J. Thromb. Haemost. 2018, 16, 1198-1210. [CrossRef]

79. Riedl, J.; Hell, L.; Kaider, A.; Koder, S.; Marosi, C.; Zielinski, C.; Panzer, S.; Pabinger, I.; Ay, C. Association of platelet activation markers with cancer-associated venous thromboembolism. Platelets 2016, 27, 80-85. [CrossRef]

80. Tesfamariam, B. Involvement of platelets in tumor cell metastasis. Pharmacol. Ther. 2016, 157, 112-119. [CrossRef]

81. Zhang, Q.; Liu, H.; Zhu, Q.; Zhan, P.; Zhu, S.; Zhang, J.; Lv, T.; Song, Y. Patterns and functional implications of platelets upon tumor "education". Int. J. Biochem. Cell Biol. 2017, 90, 68-80. [CrossRef]

82. Fricke, A.; Ullrich, P.V.; Cimniak, A.F.V.; Becherer, C.; Follo, M.; Heinz, J.; Scholber, J.; Herget, G.W.; Hauschild, O.; Wittel, U.A.; et al. Levels of activated platelet-derived microvesicles in patients with soft tissue sarcoma correlate with an increased risk of venous thromboembolism. BMC Cancer 2017, 17, 527. [CrossRef] [PubMed]

83. Riedl, J.; Pabinger, I.; Ay, C. Platelets in cancer and thrombosis. Hamostaseologie 2014, 34, 54-62. [CrossRef] [PubMed]

84. Riedl, J.; Preusser, M.; Nazari, P.M.; Posch, F.; Panzer, S.; Marosi, C.; Birner, P.; Thaler, J.; Brostjan, C.; Lotsch, D.; et al. Podoplanin expression in primary brain tumors induces platelet aggregation and increases risk of venous thromboembolism. Blood 2017, 129, 1831-1839. [CrossRef] [PubMed]

85. Lavallee, V.P.; Chagraoui, J.; MacRae, T.; Marquis, M.; Bonnefoy, A.; Krosl, J.; Lemieux, S.; Marinier, A.; Pabst, C.; Rivard, G.E.; et al. Transcriptomic landscape of acute promyelocytic leukemia reveals aberrant surface expression of the platelet aggregation agonist Podoplanin. Leukemia 2018, 32, 1349-1357. [CrossRef] [PubMed]

86. Yang, C.; Ma, R.; Jiang, T.; Cao, M.; Zhao, L.; Bi, Y.; Kou, J.; Shi, J.; Zou, X. Contributions of phosphatidylserine-positive platelets and leukocytes and microparticles to hypercoagulable state in gastric cancer patients. Tumour Biol. 2016, 37, 7881-7891. [CrossRef] [PubMed]

87. Ma, R.; Bi, Y.; Kou, J.; Zhou, J.; Shi, J. Enhanced procoagulant activity of platelets after chemotherapy in non-small cell lung cancer. Cancer Biol. 2017, 18, 627-634. [CrossRef] [PubMed] 
88. Campello, E.; Spiezia, L.; Radu, C.M.; Bulato, C.; Castelli, M.; Gavasso, S.; Simioni, P. Endothelial, platelet, and tissue factor-bearing microparticles in cancer patients with and without venous thromboembolism. Thromb. Res. 2011, 127, 473-477. [CrossRef]

89. Laresche, C.; Pelletier, F.; Garnache-Ottou, F.; Lihoreau, T.; Biichle, S.; Mourey, G.; Saas, P.; Humbert, P.; Seilles, E.; Aubin, F. Increased levels of circulating microparticles are associated with increased procoagulant activity in patients with cutaneous malignant melanoma. J. Investig. Dermatol. 2014, 134, 176-182. [CrossRef]

90. Toth, B.; Liebhardt, S.; Steinig, K.; Ditsch, N.; Rank, A.; Bauerfeind, I.; Spannagl, M.; Friese, K.; Reininger, A.J. Platelet-derived microparticles and coagulation activation in breast cancer patients. Thromb. Haemost. 2008, 100, 663-669. [CrossRef]

91. Rank, A.; Liebhardt, S.; Zwirner, J.; Burges, A.; Nieuwland, R.; Toth, B. Circulating microparticles in patients with benign and malignant ovarian tumors. Anticancer Res. 2012, 32, 2009-2014.

92. Carobbio, A.; Thiele, J.; Passamonti, F.; Rumi, E.; Ruggeri, M.; Rodeghiero, F.; Randi, M.L.; Bertozzi, I.; Vannucchi, A.M.; Antonioli, E.; et al. Risk factors for arterial and venous thrombosis in WHO-defined essential thrombocythemia: An international study of 891 patients. Blood 2011, 117, 5857-5859. [CrossRef] [PubMed]

93. Barbui, T.; Finazzi, G.; Carobbio, A.; Thiele, J.; Passamonti, F.; Rumi, E.; Ruggeri, M.; Rodeghiero, F.; Randi, M.L.; Bertozzi, I.; et al. Development and validation of an International Prognostic Score of thrombosis in World Health Organization-essential thrombocythemia (IPSET-thrombosis). Blood 2012, 120, 5128-5133. [CrossRef]

94. Moles-Moreau, M.P.; Ternisien, C.; Tanguy-Schmidt, A.; Boyer, F.; Gardembas, M.; Dib, M.; Ponthieux, A.; Guardiola, P.; Ifrah, N.; Hunault-Berger, M. Flow cytometry-evaluated platelet CD36 expression, reticulated platelets and platelet microparticles in essential thrombocythaemia and secondary thrombocytosis. Thromb. Res. 2010, 126, e394-e396. [CrossRef] [PubMed]

95. Trappenburg, M.C.; van Schilfgaarde, M.; Marchetti, M.; Spronk, H.M.; ten Cate, H.; Leyte, A.; Terpstra, W.E.; Falanga, A. Elevated procoagulant microparticles expressing endothelial and platelet markers in essential thrombocythemia. Haematologica 2009, 94, 911-918. [CrossRef]

96. Zhang, W.; Qi, J.; Zhao, S.; Shen, W.; Dai, L.; Han, W.; Huang, M.; Wang, Z.; Ruan, C.; Wu, D.; et al. Clinical significance of circulating microparticles in $\mathrm{Ph}(-)$ myeloproliferative neoplasms. Oncol. Lett. 2017, 14, 2531-2536. [CrossRef] [PubMed]

97. Villmow, T.; Kemkes-Matthes, B.; Matzdorff, A.C. Markers of platelet activation and platelet-leukocyte interaction in patients with myeloproliferative syndromes. Thromb. Res. 2002, 108, 139-145. [CrossRef]

98. Panova-Noeva, M.; Marchetti, M.; Spronk, H.M.; Russo, L.; Diani, E.; Finazzi, G.; Salmoiraghi, S.; Rambaldi, A.; Barbui, T.; Ten Cate, H.; et al. Platelet-induced thrombin generation by the calibrated automated thrombogram assay is increased in patients with essential thrombocythemia and polycythemia vera. Am. J. Hematol. 2011, 86, 337-342. [CrossRef]

99. Marchetti, M.; Castoldi, E.; Spronk, H.M.; van Oerle, R.; Balducci, D.; Barbui, T.; Rosing, J.; Ten Cate, H.; Falanga, A. Thrombin generation and activated protein $\mathrm{C}$ resistance in patients with essential thrombocythemia and polycythemia vera. Blood 2008, 112, 4061-4068. [CrossRef]

100. Pabinger, I.; Posch, F. Flamethrowers: Blood cells and cancer thrombosis risk. Hematol. Educ. Program. Am. Soc. Hematol. Am. Soc. Hematol. 2014, 2014, 410-417. [CrossRef]

101. Toth, B.; Nieuwland, R.; Liebhardt, S.; Ditsch, N.; Steinig, K.; Stieber, P.; Rank, A.; Gohring, P.; Thaler, C.J.; Friese, K.; et al. Circulating microparticles in breast cancer patients: A comparative analysis with established biomarkers. Anticancer Res. 2008, 28, 1107-1112. [PubMed]

102. Kanazawa, S.; Nomura, S.; Kuwana, M.; Muramatsu, M.; Yamaguchi, K.; Fukuhara, S. Monocyte-derived microparticles may be a sign of vascular complication in patients with lung cancer. Lung Cancer 2003, 39, 145-149. [CrossRef]

103. Kalinkovich, A.; Tavor, S.; Avigdor, A.; Kahn, J.; Brill, A.; Petit, I.; Goichberg, P.; Tesio, M.; Netzer, N.; Naparstek, E.; et al. Functional CXCR4-expressing microparticles and SDF-1 correlate with circulating acute myelogenous leukemia cells. Cancer Res. 2006, 66, 11013-11020. [CrossRef]

104. Angelillo-Scherrer, A. Leukocyte-derived microparticles in vascular homeostasis. Circ. Res. 2012, 110, $356-369$. [CrossRef] [PubMed]

105. Butenas, S.; Bouchard, B.A.; Brummel-Ziedins, K.E.; Parhami-Seren, B.; Mann, K.G. Tissue factor activity in whole blood. Blood 2005, 105, 2764-2770. [CrossRef] 
106. Shantsila, E.; Lip, G.Y. The role of monocytes in thrombotic disorders. Insights from tissue factor, monocyte-platelet aggregates and novel mechanisms. Thromb. Haemost. 2009, 102, 916-924. [CrossRef] [PubMed]

107. Lwaleed, B.A.; Francis, J.L.; Chisholm, M. Monocyte tissue factor levels in cancer patients. Saudi Med. J. 2000, 21, 722-729.

108. Arellano-Rodrigo, E.; Alvarez-Larran, A.; Reverter, J.C.; Villamor, N.; Colomer, D.; Cervantes, F. Increased platelet and leukocyte activation as contributing mechanisms for thrombosis in essential thrombocythemia and correlation with the JAK2 mutational status. Haematologica 2006, 91, 169-175.

109. Kornberg, A.; Rahimi-Levene, N.; Yona, R.; Mor, A.; Rachmilewitz, E.A. Enhanced generation of monocyte tissue factor and increased plasma prothrombin fragment1+2 levels in patients with polycythemia vera: Mechanism of activation of blood coagulation. Am. J. Hematol. 1997, 56, 5-11. [CrossRef]

110. Niemetz, J.; Fani, K. Thrombogenic activity of leukocytes. Blood 1973, 42, 47-59.

111. Aharon, A.; Tamari, T.; Brenner, B. Monocyte-derived microparticles and exosomes induce procoagulant and apoptotic effects on endothelial cells. Thromb. Haemost. 2008, 100, 878-885. [PubMed]

112. Aleman, M.M.; Gardiner, C.; Harrison, P.; Wolberg, A.S. Differential contributions of monocyteand platelet-derived microparticles towards thrombin generation and fibrin formation and stability. J. Thromb. Haemost. 2011, 9, 2251-2261. [CrossRef] [PubMed]

113. Van Der Meijden, P.E.; Van Schilfgaarde, M.; Van Oerle, R.; Renne, T.; ten Cate, H.; Spronk, H.M. Plateletand erythrocyte-derived microparticles trigger thrombin generation via factor XIIa. J. Thromb. Haemost. 2012, 10, 1355-1362. [CrossRef] [PubMed]

114. Tan, X.; Shi, J.; Fu, Y.; Gao, C.; Yang, X.; Li, J.; Wang, W.; Hou, J.; Li, H.; Zhou, J. Role of erythrocytes and platelets in the hypercoagulable status in polycythemia vera through phosphatidylserine exposure and microparticle generation. Thromb. Haemost. 2013, 109, 1025-1032. [CrossRef]

115. Zhou, J.; Zheng, Y.; Shi, J.; Lu, C.; Hou, J.; Yu, H.; Qiao, X.; Qi, S.; Gilbert, G.E. Daunorubicin induces procoagulant response through phosphatidylserine exposure in red blood cells. Thromb. Res. 2010, 125, 178-183. [CrossRef]

116. Coussens, L.M.; Werb, Z. Inflammation and cancer. Nature 2002, 420, 860-867. [CrossRef] [PubMed]

117. Comen, E.A.; Bowman, R.L.; Kleppe, M. Underlying Causes and Therapeutic Targeting of the Inflammatory Tumor Microenvironment. Front. Cell Dev. Biol. 2018, 6, 56. [CrossRef]

118. Swystun, L.L.; Liaw, P.C. The role of leukocytes in thrombosis. Blood 2016, 128, 753-762. [CrossRef]

119. Foley, J.H.; Conway, E.M. Cross Talk Pathways Between Coagulation and Inflammation. Circ. Res. 2016, 118, 1392-1408. [CrossRef]

120. Gould, T.J.; Vu, T.T.; Swystun, L.L.; Dwivedi, D.J.; Mai, S.H.; Weitz, J.I.; Liaw, P.C. Neutrophil extracellular traps promote thrombin generation through platelet-dependent and platelet-independent mechanisms. Arterioscler. Thromb. Vasc. Biol. 2014, 34, 1977-1984. [CrossRef]

121. Yang, S.; Qi, H.; Kan, K.; Chen, J.; Xie, H.; Guo, X.; Zhang, L. Neutrophil Extracellular Traps Promote Hypercoagulability in Patients With Sepsis. Shock 2017, 47, 132-139. [CrossRef]

122. He, Z.; Si, Y.; Jiang, T.; Ma, R.; Zhang, Y.; Cao, M.; Li, T.; Yao, Z.; Zhao, L.; Fang, S.; et al. Phosphotidylserine exposure and neutrophil extracellular traps enhance procoagulant activity in patients with inflammatory bowel disease. Thromb. Haemost. 2016, 115, 738-751. [CrossRef]

123. Tripodi, A.; Ammollo, C.T.; Semeraro, F.; Colucci, M.; Malchiodi, E.; Verrua, E.; Ferrante, E.; Arnaldi, G.; Trementino, L.; Padovan, L.; et al. Hypercoagulability in patients with Cushing disease detected by thrombin generation assay is associated with increased levels of neutrophil extracellular trap-related factors. Endocrine 2017, 56, 298-307. [CrossRef] [PubMed]

124. Stakos, D.A.; Kambas, K.; Konstantinidis, T.; Mitroulis, I.; Apostolidou, E.; Arelaki, S.; Tsironidou, V.; Giatromanolaki, A.; Skendros, P.; Konstantinides, S.; et al. Expression of functional tissue factor by neutrophil extracellular traps in culprit artery of acute myocardial infarction. Eur. Heart J. 2015, 36, 1405-1414. [CrossRef] [PubMed]

125. Oklu, R.; Sheth, R.A.; Wong, K.H.K.; Jahromi, A.H.; Albadawi, H. Neutrophil extracellular traps are increased in cancer patients but does not associate with venous thrombosis. Cardiovasc. Diagn. 2017, 7 (Suppl. 3), S140-S149. [CrossRef]

126. Martinod, K.; Demers, M.; Fuchs, T.A.; Wong, S.L.; Brill, A.; Gallant, M.; Hu, J.; Wang, Y.; Wagner, D.D. Neutrophil histone modification by peptidylarginine deiminase 4 is critical for deep vein thrombosis in mice. Proc. Natl. Acad. Sci. USA 2013, 110, 8674-8679. [CrossRef] [PubMed] 
127. McDonald, B.; Davis, R.P.; Kim, S.J.; Tse, M.; Esmon, C.T.; Kolaczkowska, E.; Jenne, C.N. Platelets and neutrophil extracellular traps collaborate to promote intravascular coagulation during sepsis in mice. Blood 2017, 129, 1357-1367. [CrossRef]

128. Wang, Y.; Luo, L.; Braun, O.O.; Westman, J.; Madhi, R.; Herwald, H.; Morgelin, M.; Thorlacius, H. Neutrophil extracellular trap-microparticle complexes enhance thrombin generation via the intrinsic pathway of coagulation in mice. Sci. Rep. 2018, 8, 4020. [CrossRef]

129. Yalavarthi, S.; Gould, T.J.; Rao, A.N.; Mazza, L.F.; Morris, A.E.; Nunez-Alvarez, C.; Hernandez-Ramirez, D.; Bockenstedt, P.L.; Liaw, P.C.; Cabral, A.R.; et al. Release of neutrophil extracellular traps by neutrophils stimulated with antiphospholipid antibodies: A newly identified mechanism of thrombosis in the antiphospholipid syndrome. Arthr. Rheumatol. 2015, 67, 2990-3003. [CrossRef]

130. Noubouossie, D.F.; Whelihan, M.F.; Yu, Y.B.; Sparkenbaugh, E.; Pawlinski, R.; Monroe, D.M.; Key, N.S. In vitro activation of coagulation by human neutrophil DNA and histone proteins but not neutrophil extracellular traps. Blood 2017, 129, 1021-1029. [CrossRef]

131. Abrams, S.T.; Zhang, N.; Manson, J.; Liu, T.; Dart, C.; Baluwa, F.; Wang, S.S.; Brohi, K.; Kipar, A.; Yu, W.; et al. Circulating histones are mediators of trauma-associated lung injury. Am. J. Respir. Crit. Care Med. 2013, 187, 160-169. [CrossRef] [PubMed]

132. Alhamdi, Y.; Toh, C.H. The role of extracellular histones in haematological disorders. Br. J. Haematol. 2016, 173, 805-811. [CrossRef]

133. Huang, Y.M.; Wang, H.; Wang, C.; Chen, M.; Zhao, M.H. Promotion of hypercoagulability in antineutrophil cytoplasmic antibody-associated vasculitis by C5a-induced tissue factor-expressing microparticles and neutrophil extracellular traps. Arthr. Rheumatol. 2015, 67, 2780-2790. [CrossRef] [PubMed]

134. Thalin, C.; Demers, M.; Blomgren, B.; Wong, S.L.; von Arbin, M.; von Heijne, A.; Laska, A.C.; Wallen, H.; Wagner, D.D.; Aspberg, S. NETosis promotes cancer-associated arterial microthrombosis presenting as ischemic stroke with troponin elevation. Thromb. Res. 2016, 139, 56-64. [CrossRef]

135. Yang, C.; Sun, W.; Cui, W.; Li, X.; Yao, J.; Jia, X.; Li, C.; Wu, H.; Hu, Z.; Zou, X. Procoagulant role of neutrophil extracellular traps in patients with gastric cancer. Int. J. Clin. Exp. Pathol. 2015, 8, 14075-14086.

136. Richardson, J.J.R.; Hendrickse, C.; Gao-Smith, F.; Thickett, D.R. Neutrophil Extracellular Trap Production in Patients with Colorectal Cancer In Vitro. Int. J. Inflam. 2017, 2017, 4915062. [CrossRef] [PubMed]

137. Garley, M.; Dziemianczyk-Pakiela, D.; Grubczak, K.; Surazynski, A.; Dabrowska, D.; Ratajczak-Wrona, W.; Sawicka-Powierza, J.; Borys, J.; Moniuszko, M.; Palka, J.A.; et al. Differences and similarities in the phenomenon of NETs formation in oral inflammation and in oral squamous cell carcinoma. J. Cancer 2018, 9, 1958-1965. [CrossRef]

138. Podaza, E.; Sabbione, F.; Risnik, D.; Borge, M.; Almejun, M.B.; Colado, A.; Fernandez-Grecco, H.; Cabrejo, M.; Bezares, R.F.; Trevani, A.; et al. Neutrophils from chronic lymphocytic leukemia patients exhibit an increased capacity to release extracellular traps (NETs). Cancer Immunol. Immunother. 2017, 66, 77-89. [CrossRef] [PubMed]

139. Marin Oyarzun, C.P.; Carestia, A.; Lev, P.R.; Glembotsky, A.C.; Castro Rios, M.A.; Moiraghi, B.; Molinas, F.C.; Marta, R.F.; Schattner, M.; Heller, P.G. Neutrophil extracellular trap formation and circulating nucleosomes in patients with chronic myeloproliferative neoplasms. Sci. Rep. 2016, 6, 38738. [CrossRef]

140. Demers, M.; Krause, D.S.; Schatzberg, D.; Martinod, K.; Voorhees, J.R.; Fuchs, T.A.; Scadden, D.T.; Wagner, D.D. Cancers predispose neutrophils to release extracellular DNA traps that contribute to cancer-associated thrombosis. Proc. Natl. Acad. Sci. USA 2012, 109, 13076-13081. [CrossRef]

141. Abdol Razak, N.; Elaskalani, O.; Metharom, P. Pancreatic Cancer-Induced Neutrophil Extracellular Traps: A Potential Contributor to Cancer-Associated Thrombosis. Int. J. Mol. Sci. 2017, 18, 487. [CrossRef] [PubMed]

142. Boone, B.A.; Murthy, P.; Miller-Ocuin, J.; Doerfler, W.R.; Ellis, J.T.; Liang, X.; Ross, M.A.; Wallace, C.T.; Sperry, J.L.; Lotze, M.T.; et al. Chloroquine reduces hypercoagulability in pancreatic cancer through inhibition of neutrophil extracellular traps. BMC Cancer 2018, 18, 678. [CrossRef] [PubMed]

143. Mauracher, L.M.; Posch, F.; Martinod, K.; Grilz, E.; Daullary, T.; Hell, L.; Brostjan, C.; Zielinski, C.; Ay, C.; Wagner, D.D.; et al. Citrullinated histone H3, a biomarker of neutrophil extracellular trap formation, predicts the risk of venous thromboembolism in cancer patients. J. Thromb. Haemost. 2018, 16, 508-518. [CrossRef] [PubMed]

144. Olsson, A.K.; Cedervall, J. NETosis in Cancer-Platelet-Neutrophil Crosstalk Promotes Tumor-Associated Pathology. Front. Immunol. 2016, 7, 373. [CrossRef] [PubMed] 
145. Elaskalani, O.; Abdol Razak, N.B.; Metharom, P. Neutrophil extracellular traps induce aggregation of washed human platelets independently of extracellular DNA and histones. Cell Commun. Signal. 2018, 16, 24. [CrossRef]

146. Etulain, J.; Martinod, K.; Wong, S.L.; Cifuni, S.M.; Schattner, M.; Wagner, D.D. P-selectin promotes neutrophil extracellular trap formation in mice. Blood 2015, 126, 242-246. [CrossRef] [PubMed]

147. Danckwardt, S.; Hentze, M.W.; Kulozik, A.E. Pathologies at the nexus of blood coagulation and inflammation: Thrombin in hemostasis, cancer, and beyond. J. Mol. Med. 2013, 91, 1257-1271. [CrossRef] [PubMed]

148. Bevilacqua, M.P.; Pober, J.S.; Majeau, G.R.; Fiers, W.; Cotran, R.S.; Gimbrone, M.A., Jr. Recombinant tumor necrosis factor induces procoagulant activity in cultured human vascular endothelium: Characterization and comparison with the actions of interleukin 1. Proc. Natl. Acad. Sci. USA 1986, 83, 4533-4537. [CrossRef] [PubMed]

149. Wharram, B.L.; Fitting, K.; Kunkel, S.L.; Remick, D.G.; Merritt, S.E.; Wiggins, R.C. Tissue factor expression in endothelial cell/monocyte cocultures stimulated by lipopolysaccharide and/or aggregated IgG. Mechanisms of cell:cell communication. J. Immunol. 1991, 146, 1437-1445. [PubMed]

150. Reitter, E.M.; Ay, C.; Kaider, A.; Pirker, R.; Zielinski, C.; Zlabinger, G.; Pabinger, I. Interleukin levels and their potential association with venous thromboembolism and survival in cancer patients. Clin. Exp. Immunol. 2014, 177, 253-260. [CrossRef]

151. Matsuo, K.; Hasegawa, K.; Yoshino, K.; Murakami, R.; Hisamatsu, T.; Stone, R.L.; Previs, R.A.; Hansen, J.M.; Ikeda, Y.; Miyara, A.; et al. Venous thromboembolism, interleukin-6 and survival outcomes in patients with advanced ovarian clear cell carcinoma. Eur. J. Cancer 2015, 51, 1978-1988. [CrossRef] [PubMed]

152. Du, T.; Tan, Z. Relationship between deep venous thrombosis and inflammatory cytokines in postoperative patients with malignant abdominal tumors. Braz. J. Med. Biol. Res. 2014, 47, 1003-1007. [CrossRef]

153. Stouthard, J.M.; Levi, M.; Hack, C.E.; Veenhof, C.H.; Romijn, H.A.; Sauerwein, H.P.; van der Poll, T. Interleukin-6 stimulates coagulation, not fibrinolysis, in humans. Thromb. Haemost. 1996, 76, 738-742. [CrossRef]

154. Reddel, C.J.; Allen, J.D.; Ehteda, A.; Taylor, R.; Chen, V.M.; Curnow, J.L.; Kritharides, L.; Robertson, G. Increased thrombin generation in a mouse model of cancer cachexia is partially interleukin- 6 dependent. J. Thromb. Haemost. 2017, 15, 477-486. [CrossRef] [PubMed]

155. Lysov, Z.; Swystun, L.L.; Kuruvilla, S.; Arnold, A.; Liaw, P.C. Lung cancer chemotherapy agents increase procoagulant activity via protein disulfide isomerase-dependent tissue factor decryption. Blood Coagul. Fibrinolysis 2015, 26, 36-45. [CrossRef] [PubMed]

156. Jacobsen, C.; Oechsle, K.; Hauschild, J.; Steinemann, G.; Spath, B.; Bokemeyer, C.; Ruf, W.; Honecker, F.; Langer, F. Regulation of tissue factor in NT2 germ cell tumor cells by cisplatin chemotherapy. Thromb. Res. 2015, 136, 673-681. [CrossRef] [PubMed]

157. Muhsin-Sharafaldine, M.R.; McLellan, A.D. Apoptotic vesicles: Deathly players in cancer-associated coagulation. Immunol. Cell Biol. 2018. [CrossRef]

158. Verso, M.; Agnelli, G.; Barni, S.; Gasparini, G.; LaBianca, R. A modified Khorana risk assessment score for venous thromboembolism in cancer patients receiving chemotherapy: The Protecht score. Intern. Emerg. Med. 2012, 7, 291-292. [CrossRef]

159. Kim, S.H.; Lim, K.M.; Noh, J.Y.; Kim, K.; Kang, S.; Chang, Y.K.; Shin, S.; Chung, J.H. Doxorubicin-induced platelet procoagulant activities: An important clue for chemotherapy-associated thrombosis. Toxicol. Sci. 2011, 124, 215-224. [CrossRef]

160. Wang, Z.; Wang, J.; Xie, R.; Liu, R.; Lu, Y. Mitochondria-derived reactive oxygen species play an important role in Doxorubicin-induced platelet apoptosis. Int. J. Mol. Sci. 2015, 16, 11087-11100. [CrossRef]

161. Bae, O.N.; Lim, K.M.; Noh, J.Y.; Chung, S.M.; Kim, H.; Lee, C.R.; Park, J.D.; Chung, J.H. Arsenite-enhanced procoagulant activity through phosphatidylserine exposure in platelets. Chem. Res. Toxicol. 2007, 20, 1760-1768. [CrossRef] [PubMed]

162. Gil-Bernabe, A.M.; Lucotti, S.; Muschel, R.J. Coagulation and metastasis: What does the experimental literature tell us? Br. J. Haematol. 2013, 162, 433-441. [CrossRef] [PubMed]

163. Nierodzik, M.L.; Plotkin, A.; Kajumo, F.; Karpatkin, S. Thrombin stimulates tumor-platelet adhesion in vitro and metastasis in vivo. J. Clin. Investig. 1991, 87, 229-236. [CrossRef] [PubMed]

164. Turpin, B.; Miller, W.; Rosenfeldt, L.; Kombrinck, K.; Flick, M.J.; Steinbrecher, K.A.; Harmel-Laws, E.; Mullins, E.S.; Shaw, M.; Witte, D.P.; et al. Thrombin drives tumorigenesis in colitis-associated colon cancer. Cancer Res. 2014, 74, 3020-3030. [CrossRef] 
165. Asanuma, K.; Wakabayashi, H.; Okamoto, T.; Asanuma, Y.; Akita, N.; Yoshikawa, T.; Hayashi, T.; Matsumine, A.; Uchida, A.; Sudo, A. The thrombin inhibitor, argatroban, inhibits breast cancer metastasis to bone. Breast Cancer 2013, 20, 241-246. [CrossRef] [PubMed]

166. Wojtukiewicz, M.Z.; Hempel, D.; Sierko, E.; Tucker, S.C.; Honn, K.V. Protease-activated receptors (PARs)-biology and role in cancer invasion and metastasis. Cancer Metastasis Rev. 2015, 34, 775-796. [CrossRef] [PubMed]

167. Green, D.L.; Karpatkin, S. Effect of cancer on platelets. Cancer Treat. Res. 2009, 148, 17-30. [CrossRef]

168. Bourcy, M.; Suarez-Carmona, M.; Lambert, J.; Francart, M.E.; Schroeder, H.; Delierneux, C.; Skrypek, N.; Thompson, E.W.; Jerusalem, G.; Berx, G.; et al. Tissue Factor Induced by Epithelial-Mesenchymal Transition Triggers a Procoagulant State that Drives Metastasis of Circulating Tumor Cells. Cancer Res. 2016, 76, 4270-4282. [CrossRef]

169. van Es, N.; Sturk, A.; Middeldorp, S.; Nieuwland, R. Effects of cancer on platelets. Semin. Oncol. 2014, 41, 311-318. [CrossRef]

170. Wang, S.; Li, Z.; Xu, R. Human Cancer and Platelet Interaction, a Potential Therapeutic Target. Int. J. Mol. Sci. 2018, 19, 1246. [CrossRef]

171. Buergy, D.; Wenz, F.; Groden, C.; Brockmann, M.A. Tumor-platelet interaction in solid tumors. Int. J. Cancer J. Int. Du Cancer 2012, 130, 2747-2760. [CrossRef] [PubMed]

172. Dovizio, M.; Bruno, A.; Contursi, A.; Grande, R.; Patrignani, P. Platelets and extracellular vesicles in cancer: Diagnostic and therapeutic implications. Cancer Metastasis Rev. 2018. [CrossRef] [PubMed]

173. Contursi, A.; Sacco, A.; Grande, R.; Dovizio, M.; Patrignani, P. Platelets as crucial partners for tumor metastasis: From mechanistic aspects to pharmacological targeting. Cell Mol. Life Sci. 2017, 74, 3491-3507. [CrossRef]

174. Wojtukiewicz, M.Z.; Sierko, E.; Hempel, D.; Tucker, S.C.; Honn, K.V. Platelets and cancer angiogenesis nexus. Cancer Metastasis Rev. 2017, 36, 249-262. [CrossRef] [PubMed]

175. Kanikarla-Marie, P.; Lam, M.; Menter, D.G.; Kopetz, S. Platelets, circulating tumor cells, and the circulome. Cancer Metastasis Rev. 2017, 36, 235-248. [CrossRef] [PubMed]

176. Meikle, C.K.; Kelly, C.A.; Garg, P.; Wuescher, L.M.; Ali, R.A.; Worth, R.G. Cancer and Thrombosis: The Platelet Perspective. Front. Cell Dev. Biol. 2016, 4, 147. [CrossRef]

177. Erpenbeck, L.; Schon, M.P. Deadly allies: The fatal interplay between platelets and metastasizing cancer cells. Blood 2010, 115, 3427-3436. [CrossRef] 